\title{
Assessment of Iron Toxicity in Tropical Grasses with Potential for Revegetating Mined Areas
}

\author{
Camilla Oliveira Rios, Bruna Costa de Souza, \\ Advanio Inácio Siqueira-Silva, Eduardo Gusmão Pereira* \\ Instituto de Ciências Biológicas e da Saúde, Universidade Federal de Viçosa (UFV), Campus Florestal, \\ 35690-000-Florestal, Minas Gerais, Brazil
}

Received: 14 December 2016

Accepted: 11 January 2017

\begin{abstract}
The selection of plant species resistant to iron toxicity is important in the ecological rehabilitation of mining areas. The objective of our study was to identify the degree of resistance of the grasses Paspalum densum, Hyparrhenia rufa, and Echinochloa crus-galli to iron toxicity on the basis of physiological and biochemical responses in a nutrient solution. The experiments initially consisted of hydroponic cultivation of the three plant species to evaluate short-term responses at increasing concentrations of Fe-EDTA 0.009 (control), 1, 2, 4, 7, and $9 \mathrm{mM}$; and afterward by prolonged exposure of the resistant grasses to Fe-EDTA concentrations of 0.009 and $7 \mathrm{mM}$. Iron concentration increased in the leaves of all species evaluated, showing values above the phytotoxic threshold. P. densum and E. crus-galli were selected in view of their resistance to iron toxicity, evidenced mainly by low malondialdehyde (MDA) values due to mechanisms of tolerance and avoidance. In contrast, H. rufa showed an increase in MDA values and a reduction in gas exchange, revealing considerable sensitivity to iron toxicity. The results showed the potential for using P. densum and E. crus-galli in the revegetation of areas degraded by mining iron.
\end{abstract}

Keywords: Echinochloa crus-galli, Hyparrhenia rufa, Paspalum densum, iron ore, mining site restoration

\section{Introduction}

Iron is increasingly available in the environment due to numerous anthropogenic activities, especially iron ore mining and processing, with potentially adverse impacts for ecosystems [1-2]. Although iron is an essential mineral in the growth and development of plants [3-4], concentrations above $500 \mathrm{mg} \mathrm{kg}^{-1}$ dry weight (DW) are toxic to most plant species [5-6]. Iron toxicity, however, depends generally on a species' degree of resistance

*e-mail: egpereira@ufv.br as well as on the physiological state of the plants and growth conditions [3]. An understanding of these factors is therefore important to any consideration of vegetative regeneration and ecological restoration of land contaminated by mining activity [7].

Spontaneous revegetation and vegetation succession in previously mined environments is a slow, difficult, and in many cases, impossible process $[8,9]$. This is not only due to the presence of trace metals, including iron, but also the physical characteristics of the substrate, low organic matter, and nutrient content and extreme $\mathrm{pH}$ [10], among other factors. However, the selection of species that are able to grow, develop, and complete their full life cycle 
even in the presence of trace metal contamination can increase the revegetation rate in previously mined areas. Selecting resistant species is therefore indispensable to the conservation and recovery of these environments.

In this context, grasses are pioneer species considered to possess great potential in the recovery of areas degraded by mining activities [11]. They exhibit rapid growth and an ability to generate a large number of offspring within a short life cycle, conditions that are important in the reestablishment of vegetation in mined areas [12]. However, there is no guarantee that a specific grass species will prove successful in revegetating an impacted mining area simply because it occurs in geographic proximity to the site. Further research is therefore needed to determine which species are most promising in the recovery of degraded areas. Furthermore, it is important that these studies are related to understanding the mechanisms of resistance or sensitivity reasons of species to metals and the relationship to the aerial and/or subterranean parts of the plant.

The response of plants, including grasses, to iron toxicity varies. Some species are able to accumulate and tolerate high concentrations of iron in their tissues, with only mild visual symptoms. Other species are highly sensitive and exhibit severe effects, even when iron accumulates at only moderate levels [13-16].

Exclusion and chelation of iron are among the mechanisms employed by plants that are resistant to iron overload [4]. The strategies used to achieve resistance vary between species, as well as by intensity and timing of exposure. Photosynthetic variables such as gas exchange, chlorophyll $a$ fluorescence, and chlorophyll contents can provide reliable, rapid, and quantitative information about changes in plant metabolism in a non-invasive and nondestructive way, even before detection of visual symptoms [17]. They therefore provide valuable information in selecting physiological markers of stress under metal toxicity, especially iron. It will aid future research into new species resistant to excess iron, and that are therefore appropriate for use in the revegetation of areas affected by mining and other industrial sectors.

In this study, we considered the different degrees of resistance to iron toxicity in a nutrient solution of three grass species: Paspalum densum, Hyparrhenia rufa, and Echinochloa crus-galli. The objectives of this study were to identify the degree of resistance of each of these species, and to evaluate their physiological and biochemical responses to iron toxicity, and facilitate the optimal selection of species for the revegetation of areas degraded by iron mining.

\section{Materials and Methods}

\section{Plant Material and Experimental Conditions}

The experiment was conducted under greenhouse conditions $\left(19^{\circ} 53^{\prime} 20.23^{\prime \prime} \mathrm{S}, 4^{\circ} 25^{\prime} 56.38^{\prime \prime} \mathrm{W}\right)$ using the grasses Paspalum densum, Echinochloa crus-galli, and
Hyparrhenia rufa. These species naturally occur near the mining and iron ore processing areas of the Iron Quadrangle in the state of Minas Gerais, Brazil, from which the seeds were collected. After obtaining the seeds, they were sown in sandy substrate. Post-emergence vegetative propagation was performed by separating the tillers of a single individual.

The resulting plants were transferred and acclimatized in a Hoagland hydroponic nutrient solution [18] at half ionic strength $(\mathrm{pH} 5.0)$ without aeration. The nutrient solutions were refreshed approximately every seven days, and the $\mathrm{pH}$ was adjusted daily using either $\mathrm{HCl}$ or $\mathrm{NaOH}$.

\section{Selection of Species Based on Degree of Resistance to Excess Iron}

In order to evaluate the degree of resistance to excess iron in the three species, grasses acclimatized in the nutrient solution were then directly exposed to the following ferric-ethylenediaminetetraacetic acid (Fe-EDTA) concentrations ( $\mathrm{FeSO}_{4} \cdot 7 \mathrm{H}_{2} \mathrm{O}+$ EDTA): 0.009 (control), 1, 2, 4, 7, and $9 \mathrm{mM}$. The nutrient solution was renewed every three days and the $\mathrm{pH}$ adjusted daily. For all species, short-term physiological evaluations were made up to six days after exposure to the different Fe-EDTA concentrations in the nutrient solution. Additionally, $P$. densum and E. crus-galli were evaluated for long-term responses at up to 19 and 21 days, respectively, after exposure to $7 \mathrm{mM}$ Fe-EDTA treatment, because these species showed greater degrees of resistance.

The experiment followed a randomized block design with five repetitions and six treatments for each of the three plant species. Analyses of gas exchange and chlorophyll content were undertaken during the period the species were exposed to Fe-EDTA. Lipid peroxidation and iron concentrations in plant tissues were determined at the end of the experiment.

\section{Chlorophyll Index}

Total chlorophyll, chlorophyll $a$, chlorophyll $b$, and the ratio of chlorophyll $a / b$, were determined using a portable chlorophyll meter (ClorofiLOG; Falker, Brazil).

\section{Gas Exchange}

Photosynthetic rate $(A)$, stomatal conductance $\left(g_{\mathrm{s}}\right)$, transpiration $(E)$, and the ratio between internal and external $\mathrm{CO}_{2}$ concentration $(\mathrm{Ci} / \mathrm{Ca})$ were evaluated in fully expanded leaves. Measurements were taken between 07:00 and 11:00 each day using an LCA-4 infrared gas analyzer (ADC BioScientific Ltd., Hoddesdon, UK) equipped with a photon flux density of $1,000 \mu \mathrm{mol} \mathrm{m} \mathrm{m}^{-2} \mathrm{~s}^{-1}$.

\section{Iron Concentration in Leaves}

In order to quantify the iron concentration in the grass leaves, the plant material was dried in an oven at $75^{\circ} \mathrm{C}$ 
until a constant mass was achieved. Subsequently, the material was ground and broken down in a solution of nitric perchloric acid (3:1), following the methodology proposed by Tedesco et al. [19]. The iron concentration of the extract was determined using atomic absorption spectrophotometry (GBC Avanta; GBC Scientific Equipment Ltd., Dandenong, Australia).

\section{Lipid Peroxidation}

The extent of lipid peroxidation in leaves was estimated based on malondialdehyde (MDA) concentration, a product of lipid peroxidation as proposed by $\mathrm{Du}$ and Bramlage [20], with modifications. In order to achieve this, leaf tissue weighing $160 \mathrm{mg}$ was macerated in $2 \mathrm{~mL}$ of trichloroacetic acid (TCA; 0.1\%). After centrifuging $(10,000 \times \mathrm{g}$ for 15 minutes), $500 \mu \mathrm{L}$ of the supernatant was added to a mixture of $1.5 \mathrm{~mL}$ thiobarbituric acid solution (TBA; $0.5 \%$ ), and TCA solution (20\%). The reaction was also measured without the addition of TBA, as a control. The samples were then homogenized and subjected to a water bath $\left(95^{\circ} \mathrm{C}\right)$ for a period of 25 minutes. The reaction was stopped by exposing the tubes to an ice bath. Finally, we centrifuged the resulting homogenate at $3,000 \mathrm{x} g$ for 10 minutes, and measured the absorbances at wavelengths of 440, 532, and $600 \mathrm{~nm}$ using a spectrophotometer (Genesys 10S UV-1800 UV-Vis; Thermo Fisher Scientific Inc., Madison, USA). Differences in the absorbance at 440,532 , and $600 \mathrm{~nm}$, as well as the molar extinction coefficient of $157 \mathrm{mM}^{-1} \mathrm{~cm}^{-1}$, were used to calculate MDA concentrations.

\section{Statistical Analysis}

The data obtained during the experiments were subjected to analysis of variance (ANOVA), and the means were compared using Tukey's test at 5\% probability. All analyses, including regression analysis, were made using SAEG software, version 9.2 (Fundação Arthur Bernardes, UFV, Viçosa, Brazil).

\section{Results}

Iron is Absorbed Above the Phytotoxic Threshold in Sensitive and Resistant Grasses

After six days of exposure to different Fe-EDTA concentrations, intense leaf bronzing on $H$. rufa grass was observed, but this was not the case for $P$. densum or E. crusgalli. At the end of the exposure period to high Fe-EDTA concentrations, all species showed significant increases in leaf iron content, especially $H$. rufa, which had the largest sensitivity to this metal (Fig. 1). H. rufa plants grown in moderate concentration of iron $(1 \mathrm{mM})$ accumulated approximately nine times more iron in comparison with control plants, reaching values above $600 \mathrm{mg} \mathrm{kg}^{-1} \mathrm{DW}$ within a short time of exposure (six days). The maximum iron concentration in the leaves accumulated by $H$. rufa,

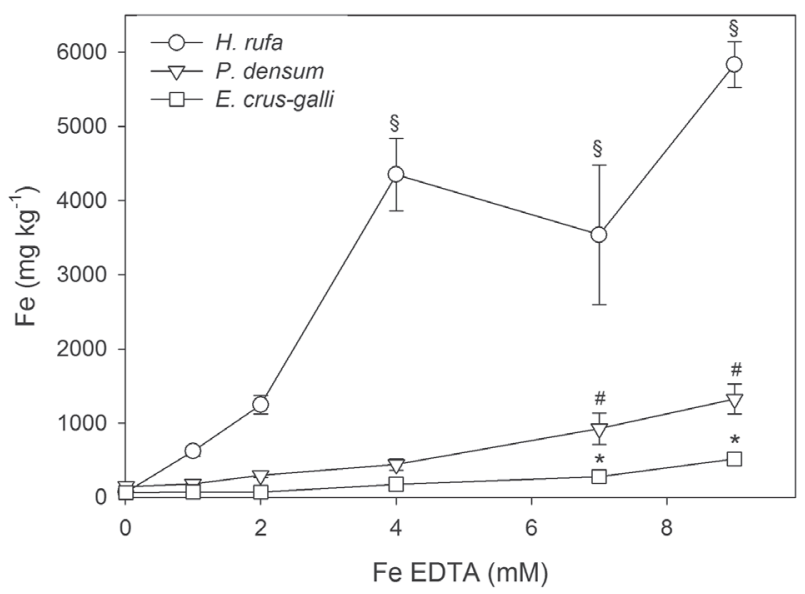

Fig. 1. Leaf iron concentration in the grass species Hyparrhenia rufa (circle), Paspalum densum (inverted triangle), and Echinochloa crus-galli (square) after exposure to different concentrations of Fe-EDTA in a nutrient solution. The bars indicate the mean \pm standard error of five repetitions. The symbols \#, *, and $\S$ indicate significant difference (Tukey's test, $5 \%$ probability) compared to the control treatment for P. densum, E. crus-galli, and $H$. rufa, respectively.

P. densum, and E. crus-galli was nearly 5,800, 1,300, and $500 \mathrm{mg} \mathrm{kg}^{-1}$, respectively (Fig. 1).

\section{Oxidative Damage is a Good Indicator of the Sensitivity of Grasses to Excess Iron}

The highest oxidative damage indicated by MDA production was observed in $H$. rufa, with increased lipid peroxidation in leaves starting at an Fe-EDTA

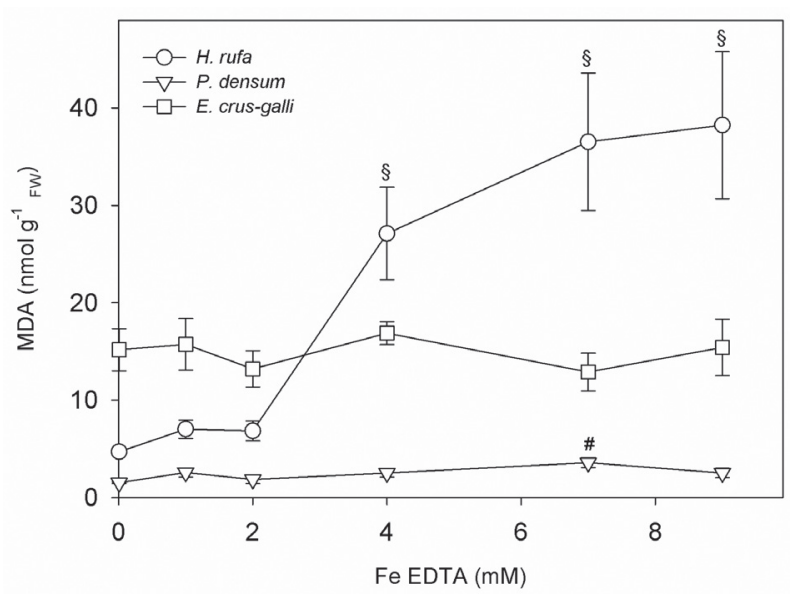

Fig. 2. Malondialdehyde concentration in the leaves of the grass species Hyparrhenia rufa (circle), Paspalum densum (inverted triangle), and Echinochloa crus-galli (square), after exposure to different concentrations of Fe-EDTA in a nutrient. The bars indicate the mean \pm standard error of five repetitions. The symbols $\S$ and \# indicate significant difference (Tukey's test, 5\% probability) for the species $H$. rufa and P. densum, respectively, as compared to control plants. 
concentration of $4 \mathrm{mM}$ (Fig. 2). Smaller MDA values occurred in $P$. densum, showing a significant increase at a concentration of $7 \mathrm{mM}$. There was no observed variation in MDA levels in E. crus-galli, regardless of the iron concentration used (Fig. 2), although this species has shown higher endogenous contents of this lipid peroxidation byproduct.

\section{Gas Exchange Responses Reflect the Degree of Resistance of Grass Species to Iron Toxicity}

Even after a short period of exposure to excess iron at moderate concentrations (2 mM Fe-EDTA), H. rufa showed a significant decrease in net photosynthetic rate. Stomatal conductance and transpiration were significantly reduced after exposure of $H$. rufa plants to $7 \mathrm{mM}$ of FeEDTA. The other species showed no significant changes in net photosynthesis, stomatal conductance, or transpiration in response to excess iron (Fig. 3). A decrease in the $\mathrm{Ci} / \mathrm{Ca}$ ratio values was observed after exposure of E. crus-galli to $1 \mathrm{mM}$ of Fe-EDTA when compared to $7 \mathrm{mM}$ Fe-EDTA treatment (Fig. 3).

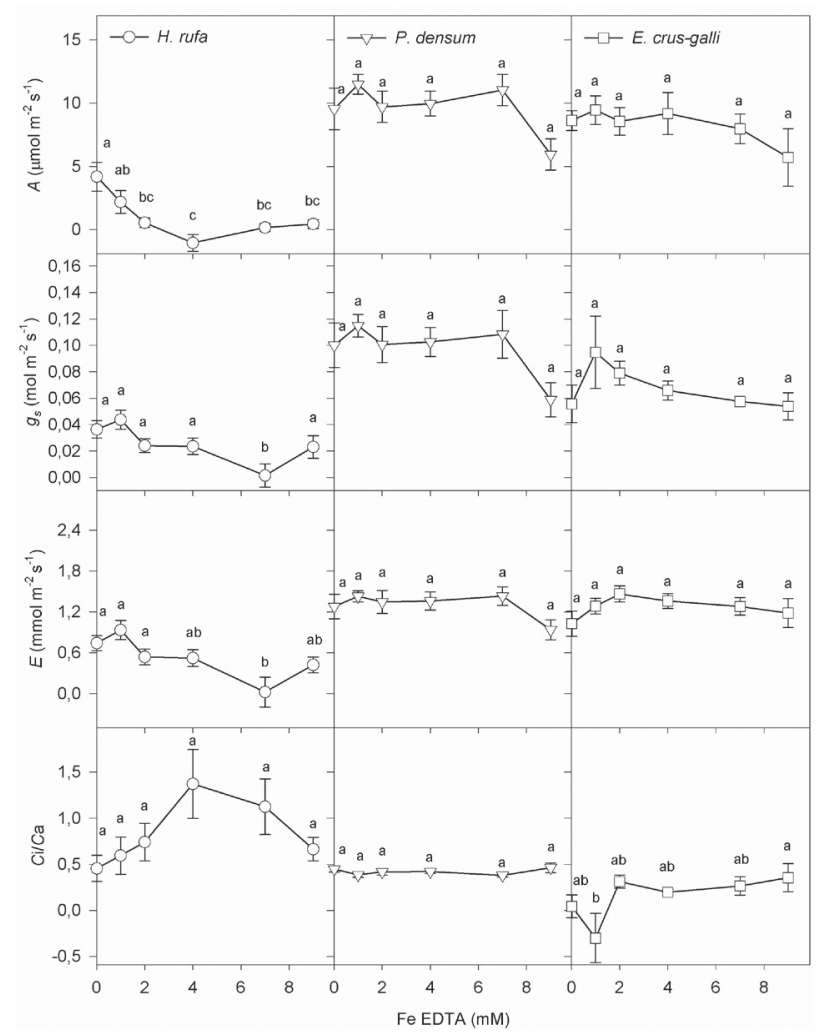

Fig. 3. Changes in net photosynthetic rate $(A)$, stomatal conductance $\left(g_{\mathrm{s}}\right)$, transpiration $(E)$, and the ratio between internal and external $\mathrm{CO}_{2}$ concentration $(\mathrm{Ci} / \mathrm{Ca})$ of the grass species Hyparrhenia rufa (circle), Paspalum densum (inverted triangle), and Echinochloa crus-galli (square) after a short exposure (six days) to different concentrations of Fe-EDTA in a nutrient solution. The bars represent the mean \pm standard error of five repetitions, and means followed by the same letters for a given species do not differ by Tukey's test at the 5\% significance level.
The prolongation of plant exposure to $\mathrm{Fe}$ excess ( 7 mM of Fe-EDTA) for 19 days did not result in decreased photosynthesis for P. densum (Fig. 4a). E. crus-galli only showed a significant difference in photosynthetic rate on the $15^{\text {th }}$ day of exposure (Fig. 4b). After four days of exposure to excess iron, there was an increase in stomatal conductance in $P$. densum leaves, whereas no significant change was observed in E. crus-galli, regardless of the time of exposure (Figs 4e-f). No significant changes were observed in either the transpiration rate or $\mathrm{Ci} / \mathrm{Ca}$ ratio during the period of exposure to excess iron in the two resistant grasses (Figs 4c-d, g-h).

\section{Iron-Resistant Grasses may Show Changes in Photosynthetic Pigments}

No significant changes were observed for chlorophyll $a$, chlorophyll $b$, total chlorophyll, or the ratio of chlorophyll $a / b$ in the species $H$. rufa and $P$. densum after a week of

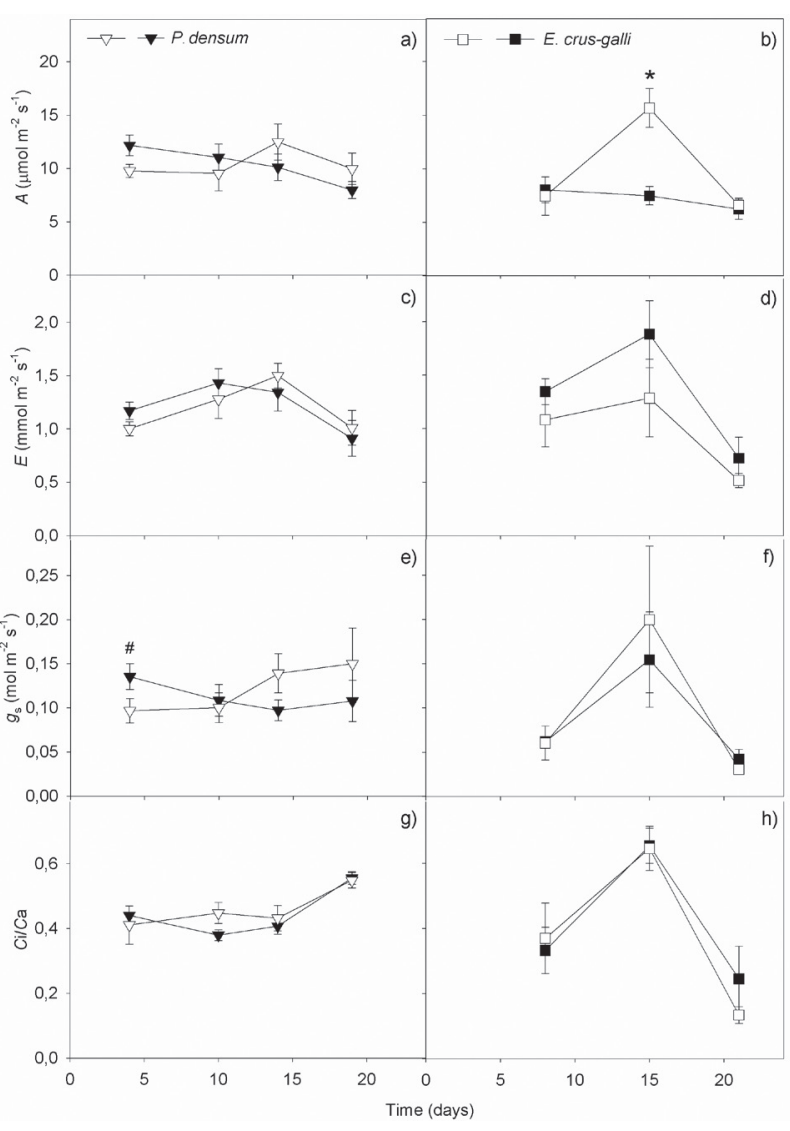

Fig. 4. Long-term changes in net photosynthetic rate, A [a) and b)], transpiration, E [c) and d)], stomatal conductance, gs [e) and $\mathrm{f}$ ], and the ratio between internal and external concentration of $\mathrm{CO}_{2}, \mathrm{Ci} / \mathrm{Ca}[\mathrm{g})$ and $\mathrm{h}$ )] in the grass species Paspalum densum (inverted triangle), and Echinochloa crus-galli (square). Measurements were taken after 19 and 21 days, respectively, in nutrient solution under control conditions $(0.009 \mathrm{mM}$ of Fe-EDTA; open symbols), and $7 \mathrm{mM}$ of Fe-EDTA (closed symbols). The bars indicate the mean \pm standard error of five repetitions. The symbols \# and * indicate significant differences (Tukey's test, $5 \%$ probability) for $P$. densum and E. crus-galli, respectively. 


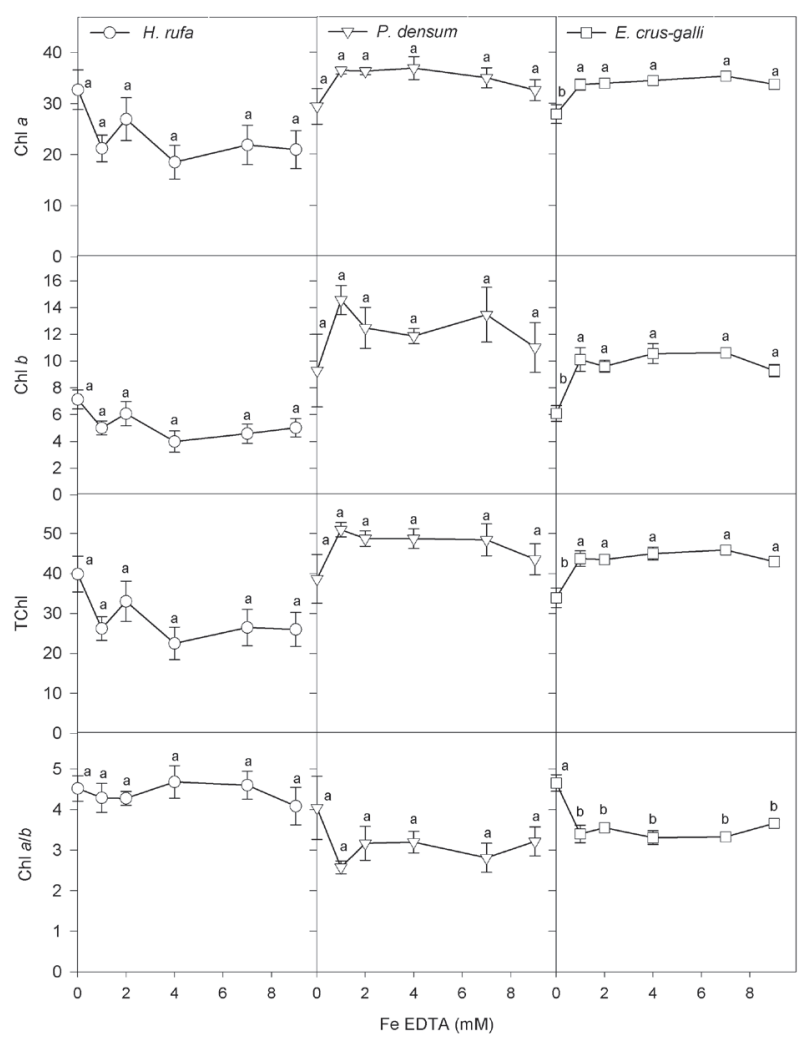

Fig. 5. Index of chlorophyll $a(\mathrm{Chl} a)$, chlorophyll $b(\mathrm{Chl} b)$, total chlorophyll (TChl), and ratio of chlorophyll $a / b(\mathrm{Chl} a / b)$ for the grass species Hyparrhenia rufa (circle), Paspalum densum (inverted triangle), and Echinochloa crus-galli (square) briefly exposed to different concentrations of Fe-EDTA in a nutrient solution. The bars represent the mean \pm standard error of five repetitions, and means followed by the same letters for a given species do not differ by Tukey's test at the $5 \%$ significance level.

exposure to increasing concentrations of Fe-EDTA in hydroponic solution (Fig. 5). In contrast, E. crus-galli showed a significant increase in chlorophyll $a$, chlorophyll $b$, and total chlorophyll content, and a decrease in the ratio of chlorophyll $a / b$ when exposed to iron concentrations above $0.009 \mathrm{mM}$ (Fig. 5).

After eight days of exposure to a phytotoxic iron concentration $(7 \mathrm{mM})$, elevated values were observed in E. crus-galli for total chlorophyll, chlorophyll $a$, and chlorophyll $b$, and a decrease in the chlorophyll $a / b$ ratio (Figs $6 \mathrm{~b}, \mathrm{~d}, \mathrm{f}$, and h). For $P$. densum, exposure to excess iron also resulted in an increase in chlorophyll $b$ content 19 days after exposure, and a decrease in the chlorophyll $a / b$ ratio (Figs. 6e and g), with no change to total chlorophyll or to chlorophyll $a$, regardless of exposure time (Figs 6a and c).

\section{Discussion}

Excess iron in the environment is toxic to many plant species. The effective vegetative recolonization of land exposed to trace metals by mining activity therefore depends on an understanding of the varying resistance of

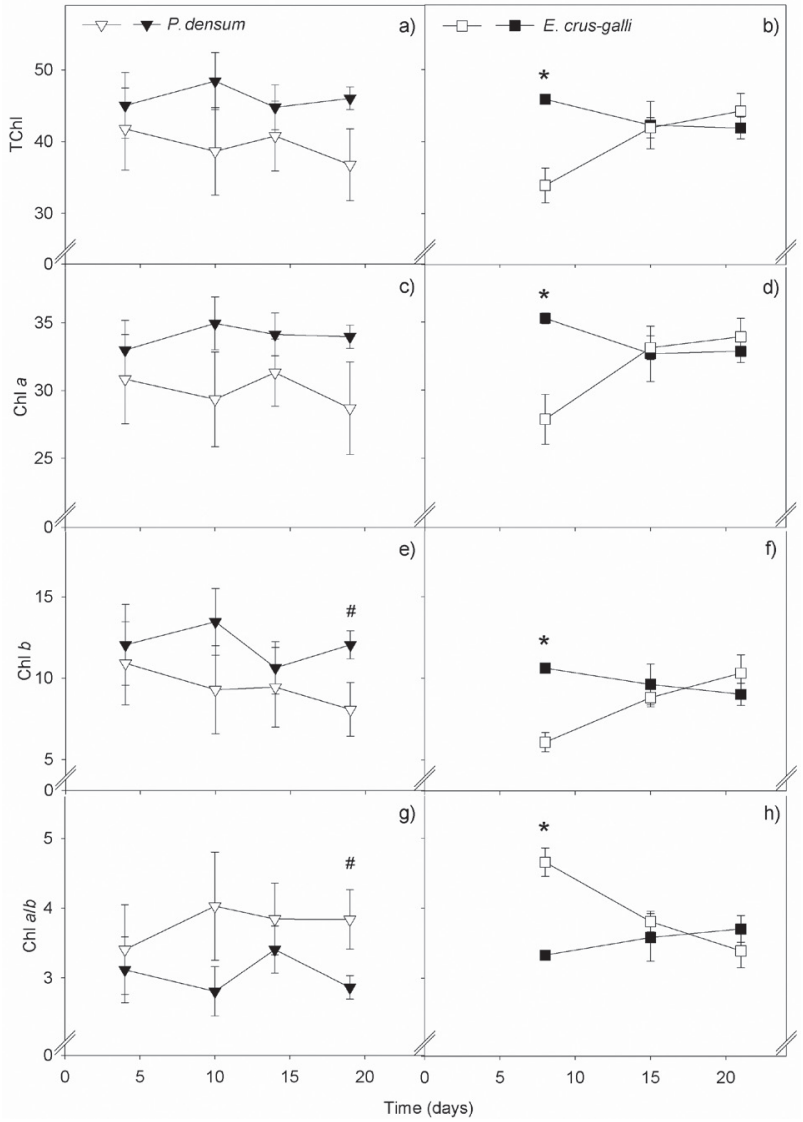

Fig. 6. Long-term changes in total chlorophyll, TChl [a) and b)], chlorophyll $a, \mathrm{Chl} a$ [c) and d)], chlorophyll $b, \mathrm{Chl} b[\mathrm{e}$ ) and f)], and the ratio of chlorophyll $a / b, \mathrm{Chl} a / b[\mathrm{~g})$ and $\mathrm{h}$ )] for the grass species Paspalum densum (inverted triangle) and Echinochloa crus-galli (square) under control conditions $(0.009 \mathrm{mM}$ of $\mathrm{Fe}-$ EDTA; open symbol), and $7 \mathrm{mM}$ of Fe-EDTA (closed symbol) in nutrient solution after 19 and 21 days of exposure, respectively. The bars indicate the mean \pm standard error of five repetitions. The symbols \# and * indicate significant differences (Tukey's test, 5\% probability) for $P$. densum and E. crus-galli, respectively.

different plant species to metal toxicity. As demonstrated in this study, it is possible to determine which of three grasses were resistant to excess iron in a nutrient solution, and which therefore could be suitable for revegetation of contaminated sites.

In all three species reviewed in this study ( $P$. densum, E. crus-galli, and H. rufa), the accumulation of iron in the leaves was higher than the concentrations normally required by the plants for normal functioning [3], reaching values considered phytotoxic (above $500 \mathrm{mg} \mathrm{kg}^{-1}$ ) in $H$. rufa and $P$. densum [5-6]. However, homeostasis was maintained without harmful effects in response to excess iron in P. densum and E. crus-galli, while H. rufa showed severe effects of iron toxicity as a result of oxidative stress induction after metal accumulation. Although this indicated the potential usefulness of $P$. densum and $E$. crus-galli for the restoration of environments affected by mining, it also demonstrated that the iron concentration in 
the tissues of the studied grasses is not a good indicator of tolerance or sensitivity to this metal, as has already been demonstrated for other species [21].

Iron is an essential element for the biosynthesis of chlorophyll [5], but exposure of plants to higher concentrations can cause degradation of chloroplastidial pigments due to oxidative stress [17, 22-23]. However, the maintenance of chlorophyll content after exposure to extreme concentrations of Fe-EDTA indicates that even the most sensitive species evaluated in this study ( $H$. rufa) has a high nutritional requirement for this micronutrient, as noted for $\mathrm{C} 4$ grasses [5, 24]. The resistant species were distinguished by the capability to maintain a satisfactory chlorophyll content, without affecting chlorophyll biosynthesis or degradation $(P$. densum), or presenting metabolic adjustment with increased investment in chlorophyll due to excess iron (E. crus-galli).

One possible explanation for the different responses observed is the ability to control the adverse effects of reactive oxygen species (ROS). The absorption and excessive accumulation of iron in plants can increase the formation of ROS, therefore causing oxidative damage in plants $[4,25]$. Increases in MDA, a lipid peroxidation byproduct, are considered an important indicator of oxidative stress in plants $[13,26]$. The low MDA concentration presented by $P$. densum and E. crus-galli after exposure to different iron concentrations is therefore indicative of an ROS control mechanism. It is likely that efficient mechanisms of tolerance and iron avoidance in P. densum and E. crus-galli, respectively, may have prevented any deleterious effects caused by iron overload. Morphophysiological, biochemical, and molecular mechanisms may act together in strategies of avoidance, isolation, and compartmentalization of phytotoxic metals [27]. In contrast, although $H$. rufa showed a greater capacity to accumulate iron in its leaves, it was unable to tolerate the oxidative stress induced by excess iron in its tissues, as evidenced by the high MDA content.

Moreover, even with high iron accumulation, $H$. rufa was not able to induce resistance mechanisms. This resulted in oxidative damage to leaf tissues; loss of photosynthetic capacity has also been reported through both stomatal and non-stomatal limitations [17]. Changes in gas exchange variables have also been reported for other plant species when exposed to high iron concentrations in the environment [3, 22-23]. The species $P$. densum and E. crus-galli, grown in nutrient solution with toxic iron content, retained the ability to maintain photosynthesis, stomatal conductance, and transpiration, and showed no oxidative damage. This serves to demonstrate the resistance of these species to excess iron. It can therefore be concluded that the treatments and methodology used were effective with respect to the selection of species appropriate for revegetation of previously mined sites, as well as to the different physiological responses.

Based on these results, it was possible to attest to the resistance of two species of grasses to iron toxicity. Investigations under field conditions are being carried out, with the objective of applying the results obtained under greenhouse conditions, and to further explore the resistance mechanisms employed by the grasses $P$. densum and E. crus-galli.

\section{Conclusions}

The grasses $P$. densum and E. crus-galli showed significant resistance to excess iron in a nutrient solution, making them promising species for use in revegetating areas affected by iron mining. The same result was not observed for $H$. rufa, because the accumulation of large amounts of iron in its leaf tissues resulted in severe oxidative damage as well as limitations in photosynthetic capacity. Depending on the physiological responses and iron accumulation in $P$. densum and E. crus-galli, the likely mechanisms of resistance in response to iron stress are tolerance and avoidance, respectively.

\section{Acknowledgements}

The authors thank Fundação de Amparo a Pesquisa do Estado de Minas Gerais (FAPEMIG) and Vale S.A. for financial support. Souza B. C. and Rios C. O. are grateful to the Conselho Nacional de Desenvolvimento Científico e Tecnológico (CNPq) and Vale S.A. for scholarships.

\section{References}

1. ARRIVABENE H.P., SOUZA I.D.C., CÓ W.L.O., CONTI M.M., WUNDERLIN D.A., MILANEZ C.R.D. Effect of pollution by particulate iron on the morphoanatomy, histochemistry, and bioaccumulation of three mangrove plant species in Brazil. Chemosphere, 127, 27, 2015.

2. PEREIRA A.A., VAN HATTUM B., BROUWER A., VAN BODEGOM P.M., REZENDE C.E., SALOMONS W. Effects of iron-ore mining and processing on metal bioavailability in a tropical coastal lagoon. Journal of Soils and Sediments, 8 (4), 239, 2008.

3. ADAMSKI J.M., PETERS J.A., DANIELOSKI R., BACARIN M.A. Excess iron-induced changes in the photosynthetic characteristics of sweet potato. Journal of Plant Physiology, 168 (17), 2056, 2011.

4. ROUT J.R., BEHERA S., KESHARI N., RAM S.S., BHAR S., CHAKRABORTY A., SUDARSHAN M., SAHOO S.L. Effect of iron stress on Withania somnifera L.: antioxidant enzyme response and nutrient elemental uptake of in vitro grown plants. Ecotoxicology, 24 (2), 401, 2015.

5. BROADLEY M., BROWN P., CAKMAK I., RENGEL Z., ZHAO F. Function of Nutrients: Micronutrients. In Marschner's Mineral Nutrition of Higher Plants. Elsevier Ltd; 191, 2012.

6. PUGH R.E., DICK D.G., FREDEEN A.L. Heavy metal (Pb, $\mathrm{Zn}, \mathrm{Cd}, \mathrm{Fe}$, and $\mathrm{Cu}$ ) contents of plant foliage near the Anvil Range lead/zinc mine, Faro, Yukon Territory. Ecotoxicology and Environmental Safety, 52 (3), 273, 2002.

7. COOKE J.A., JOHNSON M.S. Ecological restoration of land with particular reference to the mining of metals and industrial minerals: A review of theory and practice. Environmental Reviews, 10 (1), 41, 2002. 
8. MALCOVÁ R., ALBRECHTOVÁ J., VOSÁTKA M. The role of the extraradical mycelium network of arbuscular mycorrhizal fungi on the establishment and growth of Calamagrostis epigejos in industrial waste substrates. Applied Soil Ecology, 18 (2), 129, 2001.

9. SILVA G.P., FONTES M.P.F., COSTA L.M., VENEGAS V.H.A. Potencialidade de plantas para revegetação de estéreis e rejeito da mineração de ferro da mina de alegria, Mariana-MG. Pesquisa Agropecuária Tropical 36 (3), 165, 2006.

10. LIEBENBERG D., CLAASSENS S., VAN RENSBURG L. Insights and lessons learned from the long-term rehabilitation of an iron ore mine. International Journal of Environmental Research, 7 (3), 633, 2013.

11. MAITI S.K., MAITI D. Ecological restoration of waste dumps by topsoil blanketing, coir-matting and seeding with grass-legume mixture. Ecological Engineering, 77, 74, 2015.

12. JACOBI C.M., DO CARMO F.F., VINCENT R.D.C. Phytosociological study of a plant community on ironstone as support for recovery of a mined area in the iron quadrangle, MG. Revista Árvore, 32 (2), 345, 2008.

13. JUCOSKI G.O., CAMBRAIA J., RIBEIRO C., OLIVEIRA J.A., PAULA S.O., OLIVA M.A. Impact of iron toxicity on oxidative metabolism in young Eugenia uniflora L. plants. Acta Physiologiae Plantarum, 35 (5), 1645, 2013.

14. ARAÚJO T.O., FREITAS-SILVA L., SANTANA B.V., KUKI K.N., PEREIRA E.G., AZEVEDO A.A., SILVA L.C. Morphoanatomical responses induced by excess iron in roots of two tolerant grass species. Environmental Science and Pollution Research International, 22 (3), 2187, 2015.

15. MÜLLER C., KUKI K.N., PINHEIRO D.T., DE SOUZA L.R., SIQUEIRA SILVA A.I., LOUREIRO M.E., OLIVA M.A., ALMEIDA A.M. Differential physiological responses in rice upon exposure to excess distinct iron forms. Plant and Soil, 391 (1-2), 123, 2015.

16. SIQUEIRA-SILVA A.I., SILVA L.C., AZEVEDO A.A., OLIVA M.A. Iron plaque formation and morphoanatomy of roots from species of restinga subjected to excess iron. Ecotoxicology and Environmental Safety, 78, 265, 2012.

17. PEREIRA E.G., OLIVA M.A., ROSADO-SOUZA L., MENDES G.C., COLARES D.S., STOPATO C.H., ALMEIDAA.M. Iron excess affects rice photosynthesis through stomatal and non-stomatal limitations. Plant Science, 201-202 (1), 81, 2013.
18. HOAGLAND D.R., ARNON D.I. The water culture method for growing plants without soil. Berkeley: California Agricultural Experiment Station; 1950.

19. TEDESCO M.J., GIANELLO C., BISSANI C.A., BOHNEN H., VOLKWEISS S.J. Análise de solo, plantas e outros materiais, 2 ed. Porto Alegre: Universidade Federal do Rio Grande do Sul; 1995.

20. DU Z., BRAMLAGE W.J. Modified thiobarbituric acid assay for measuring lipid oxidation in sugar-rich plant tissue extracts. Journal of Agricultural and Food Chemistry, 40, 1566, 1992.

21. ELEC V., QUIMIO C.A., MENDOZA R., SAJISE A.G. C., BEEBOUT S.E.J., GREGORIO G.B., SINGH R.K. Maintaining elevated $\mathrm{Fe}^{2+}$ concentration in solution culture for the development of a rapid and repeatable screening technique for iron toxicity tolerance in rice (Oryza sativa L.). Plant and Soil, 372 (1-2), 253, 2013.

22. SILVA L.C., ARAÚJO T.O., MARTINEZ C.A., LOBO F.D.A., AZEVEDO A.A., OLIVA M.A. Differential responses of $\mathrm{C} 3$ and CAM native Brazilian plant species to a $\mathrm{SO}_{2}$ - and SPMFe - contaminated Restinga. Environmental Science and Pollution Research, 22 (18), 14007, 2015.

23. XU S., LIN D., SUN H., YANG X., ZHANG X. Excess iron alters the fatty acid composition of chloroplast membrane and decreases the photosynthesis rate: a study in hydroponic pea seedlings. Acta Physiologiae Plantarum, 37 (10), 1, 2015.

24. SMITH G.S., CORNFORTH I.S., HENDERSON H.V. Iron requirements of $\mathrm{C} 3$ and $\mathrm{C} 4$ plants. New Phytologist, 97 (4), $543,1984$.

25. NEVES N.R., OLIVA M.A., DA CRUZ CENTENO D., COSTA A.C., RIBAS R.F., PEREIRA E.G. Photosynthesis and oxidative stress in the restinga plant species Eugenia uniflora L. exposed to simulated acid rain and iron ore dust deposition: Potential use in environmental risk assessment. Science of the Total Environment, 407 (12), 3740, 2009.

26. PINTO S.S., DE SOUZA A.E., OLIVA M.A., PEREIRA E.G. Oxidative damage and photosynthetic impairment in tropical rice cultivars upon exposure to excess iron. Scientia Agricola, 73 (3), 217, 2016.

27. SILVA J.O.C., PAIVA E.A.S., MODOLO L.V., NASCENTES C.C., FRANÇA M.G.C. Removal of root apices enables study of direct toxic effects of aluminum on rice (Oryza sativa L.) leaf cells. Environmental and Experimental Botany, 95, 41, 2013 
